\title{
Penguatan Konsep Matematika Dalam Pembelajaran Latex untuk Siswa SMP dan SMA
}

\author{
Edi Kurniadi ${ }^{1}$, Herlina Napitupulu ${ }^{2}$, Alit Kartiwa ${ }^{3}$, Riaman $^{4}$ \\ 1,2,3,4 Departemen Matematika FMIPA Unpad \\ Jl. Raya Bandung Sumedang Km 21 Jatinangor, Sumedang, Jawa Barat, Indonesia 45361 \\ edi.kurniadi@unpad.ac.id
}

\begin{abstract}
In this paper, we learn the concept of coding using Latex through the strengthen of mathematics concept for junior and senior high school. The aim of this research is to attract the passion of students to learn coding through the strengthen of mathematics concept by introducing what we called a Latex program. It is an alternative software to write mathematics formulas instead of Microsoft Word. We applied qualitative descriptive method to describe the students ability in understanding of mathematical concept. We trained students how to have good knowledge of basic mathematics concept, particularly how to read and how to write mathematics formulas sistematically. As results, students could write the mathematics formulas in Latex program and have a good concept of mathematics which can be a foundation to understand the concept of coding for higher level. For future research, it is interesting to realize the concept of mathematics in the Python programming and another language program. We believe that students shall enjoy of mathematics learning using these programs.
\end{abstract}

Key words: Coding, Latex, Mathematics Formulas, Python Programming.

\begin{abstract}
Abstrak
Dalam artikel ini, kita belajar konsep coding dengan Latex melalui penguatan konsep matematika untuk siswa SMP dan SMA. Tujuan penelitian ini adalah untuk menarik minat para siswa dalam mempelajari coding melalui penguatan konsep matematika yang baik dan benar dengan memperkenalkan apa yang disebut Program Latex. Program Latex ini merupakan perangkat lunak alternatif selain Microsoft Word untuk pengetikan rumus-rumus matematika. Selanjutnya, metode yang digunakan dalam penelitian ini adalah deskriptif kualitatif untuk menggambarkan kemampuan siswa dalam memahami konsep dasar matematika dan implementasinya melalui pengetikan rumus-rumus matematika dengan Latex. Siswa dilatih agar supaya mempunyai pengetahuan yang baik dan benar tentang konsep dasar matematika, khususnya bagaimana cara membaca dan menulis rumus matematika secara sistematis. Hasil dari penelitian ini, para siswa dapat menulis rumus-rumus matematika dalam Program Latex dan mempunyai pemahaman konsep matematika yang baik dan benar yang tentunya akan menjadi modal dasar untuk memahami konsep coding untuk tingkatan yang lebih tinggi. Untuk penelitian selanjutnya, konsep matematika dapat direalisasikan melalui Pemograman Python. Melalui pendekatan Program Python ini, diharapkan para siswa akan menyukai penerapan-penerapan matematika dalam berbagai hal.
\end{abstract}

Kata kunci: Coding, Latex, Rumus Matematika, Program Python.

Copyright (c) 2021 Edi Kurniadi, Herlina Napitupulu, Alit Kartiwa, Riaman

$\triangle$ Corresponding author: Edi Kurniadi

Email Address: edi.kurniadi@unpad.ac.id (Jl. Raya Bogor, RT.3/RW.4, Jakarta)

Received 30 November 2020, Accepted 03 Februari 2021, Published 03 Februari 2021

\section{PENDAHULUAN}

Proses atau aktivitas pembelajaran matematika dapat dilaksanakan dari berbagai aspek pembelajaran seperti peningkatan analisis kemampuan komunikasi matematis dalam materi statistika (Khadijah, Maya, \& Setiawan, 2018), pengembangan media pembelajaran smartphone learning system (Putra, Sudiana, \& Pamungkan, 2020), media pembelajaran berbasis android(Suddin \& Deda, 
2020), pendekatan somatik, auditori, visual, dan intelektual (Supiyati, 2014). Selain itu, pembelajaran matematika dapat dilakukan berbasis pada alat peraga dan software atau perangkat lunak yaitu dengan integrasi teknologi (Aminah \& Waluya S.B, 2020) dan ICT (Irawati, 2015). Banyak penelitian yang sudah dilakukan tentang pemanfaatan software dalam pembelajaran matematika. Misalnya dengan pemanfaatan software Geogebra online berbasis scaffolding (Miatun \& Khusna, 2020), pembelajaran geometri untuk siswa SMP dapat dibantu melalui software Geogebra (Simbolon, 2020), pembelajaran matematika kreatif untuk meningkatkan kemampuan berpikir dengan Geogebra (Septian, Sugiarni, \& Monariska, 2020), penerapan PBL dengan RME melalui Geogebra (Puspitasari, Fuazan, \& Bernard, 2019). Selain Geogebra, pembelajaran matematika juga dapat diimplementasikan dengan Microsoft Excel (Minarni, Napitupulu, E.Elpis, \& Kusumah, 2020), Geoklik (Hendroanto \& Fitriyani, 2019), dan formulator Tarsia (Afifah, 2017).

Pada umumnya para siswa akan lebih merasa tertantang untuk memahami lebih jauh tentang konsep matematika yang sedang diajarkan oleh guru apabila pembelajaran dilaksanakan melalui bantuan alat peraga atau software. Masih banyak lagi software gratis yang dapat digunakan untuk membantu dalam proses pembelajaran matematika. Untuk tingkat lebih lanjut, misalnya dapat digunakan software Matlab, Maple, dan Mathematica. Dengan software-software tersebut diharapkan dapat menjadi alat bantu untuk memperjelas konsep yang diajarkan kepada para siswa. Hal ini sebagai upaya untuk meningkatkan penguasaan para siswa terhadap konsep matematika dan keterampilan dasar berhitung yang faktanya masih rendah (Rizali, 2018). Selain penggunaan software di atas, pembelajaran matematika juga dapat dilakukan dengan alat peraga permainan matematika. Sebagai contoh, untuk mempermudah konsep penjumlahan pecahan untuk siswa SD dapat dilakukan melalui alat peraga matematika permainan (Kurniadi, Gusriani, Subartini, \& Napitupulu, 2020).

Di sisi lain, rumus-rumus matematika juga menjadi daya tarik tersendiri untuk dipelajari khususnya bagaimana mengetik rumus-rumus tersebut. Berbeda dengan Microsoft Word yang sudah menyediakan Program Mathematics Equations untuk pengetikan rumus-rumus matematika, Program Latex menuntut para siswa untuk mengeset rumus-rumus tersendiri terlebih dahulu kemudian menjalankan program tersebut. Dengan kata lain, penulisan rumus-rumus matematika dalam Latex tidak dapat dilakukan secara instan tapi harus melalui algoritma yang baik dan benar. Jika program yang dijalankan berhasil, salah satu luarannya dapat dinyatakan dalam format Pdf (Lamport, 1986).

Lebih jauh, Program Latex ini dapat digunakan sebagai sarana penguatan konsep matematika sekaligus penerapan konsep matematika dalam kehidupan sehari-hari khususnya dalam pemahaman konsep coding. Secara sederhana coding dapat diartikan sebagai computer programming. Dengan coding seolah-olah kita memberikan instruksi kepada komputer untuk melakukan sesuatu yang kita inginkan. Coding memungkinkan kita membuat aplikasi untuk ponsel pintar, perangkat lunak, dan laman atau website. Karena dalam Latex penulisan rumus-rumus matematika harus melalui algoritma yang baik dan benar, maka Latex dapat dijadikan modal dasar untuk mempelajari coding. Tentu saja, hal ini menuntut para siswa agar mempunyai logika berpikir yang sistematis, baik, dan benar. 
Penguatan Konsep Matematika Dalam Pembelajaran Latex untuk Siswa SMP dan SMA, Edi Kurniadi, Herlina Napitupulu , Alit Kartiwa, Riama

Tujuan penelitian ini adalah untuk memperkenalkan Program Latex kepada siswa SMP dan SMA sebagai dasar untuk mempelajari coding. Pembelajaran dengan Latex ini diharapkan dapat memberikan motivasi kepada para siswa bagaimana belajar matematika yang menyenangkan dan juga memberikan manfaat dalam kehidupan sehari-hari. Sebagai contoh, seorang siswa yang mempunyai dasar matematika yang kuat akan menjadi dasar untuk memahami coding dengan lebih mudah. Di era Revolusi Industri 4.0 ini, coding sangat diperlukan seperti untuk membuat berbagai aplikasi. Seseorang yang mempunyai pengetahuan dan keterampilan bagus tentang coding akan banyak dibutuhkan oleh perusahaan. Dengan pemahaman Latex ini, diharapkan para siswa mempunyai bekal untuk memplejari $\mathrm{C}++$, Python, dan bahasa pemrograman lainnya.

\section{METODE}

Dalam penelitian ini, metode yang digunakan adalah deskriptif kualitatif seperti dalam diagram alir berikut ini.

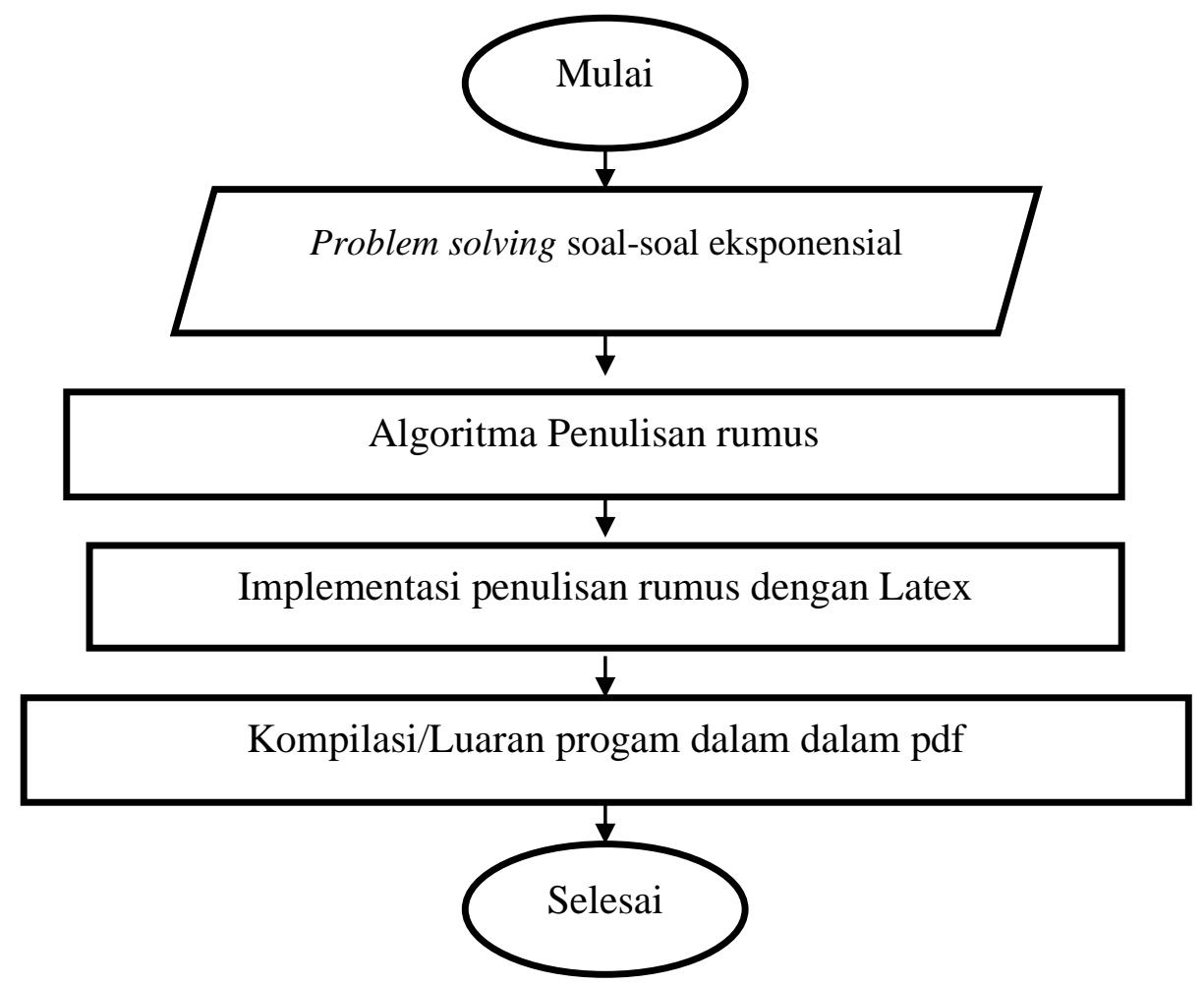

Diagram 1. Diagram alir penelitian

Pola pembelajaran yang dilakukan berfokus kepada siswa atau Student Center Learning (SCL) (Brown, 1994) dengan berbasis pada penyelesaian masalah (Problem Solving) tentang pemahaman rumus-rumus matematika dan pengetikannya dalam Program Latex. Tahapannya dilakukan sebagai berikut: Pertama-tama para siswa diberikan soal-soal matematika tentang persamaan eksponensial dan logaritma sebanyak empat soal dan mendiskusikan bagaimana menyelesaikannya. Ke dua, para siswa diajak berlatih untuk menuliskan rumus-rumus tersebut dengan Latex. Ke tiga, memeriksa algoritma pembuatan rumus matematika sebelum Program Latex 
dijalankan. Ke empat, luaran Program Latex yang dihasilkan adalah dalam bentuk Pdf. Selain itu, kegiatan pengajaran ini diselingi juga dengan pemberian motivasi kepada para siswa untuk menarik minat belajar siswa.

\section{HASIL}

Pada bagian ini diberikan beberapa soal (Wagiman \& Sularno, 1991) dan (Johansyah,Muh.Deni \& et al, 2004) untuk didiskusikan cara menyelesaikannya dan kemudian dbuat algoritmanya supaya dapat ditik dalam Latex. Adapun soal-soal tersebut adalah sebagai berikut:

1. Tentukan bilangan real $x$ yang memenuhi persamaan

$$
4^{3-2 x}=\frac{1}{8} \sqrt{32^{x}}
$$

2. Nilai dari $1-\frac{3}{4} a$ jika $a$ memenuhi persamaan

$$
\left(\sqrt[3]{\frac{1}{243}}\right)^{3 x}=\left(\frac{3}{3^{x-2}}\right)^{2} \sqrt[3]{\frac{1}{9}}
$$

3. Hasil penjumlahan $a+b$ jika $a$ dan $b$ memenuhi persamaan

$$
2.9^{2 x-1}-5.3^{2 x}+18=0 .
$$

4. Nilai $p$ yang memenuhi persamaan berikut

$$
{ }^{2} \log \left[{ }^{2} \log \left(2^{p+1}+3\right)\right]=1+{ }^{2} \log p .
$$

Untuk menyelesaikan soal-soal tersebut, para siswa diharapkan sudah mempunyai pemahaman tentang eksponesial dan logaritma. Dalam hal ini, kita menjelaskan kembali materi akar, pangkat, dan logaritma kepada para siswa yang berkaitan dengan tiap-tiap soal tersebut, kemudian berdiskusi bagaimana solusi terbaik untuk mendapatkan penyelesaiannya. Soal nomor 1 dan 2 di atas, dapat diselesaikan dengan menggunakan sifat-sifat pangkat dan akar suatu bilangan. Dengan sifat-sifat tersebut, siswa akhirnya memperoleh jawaban sebagai berikut:

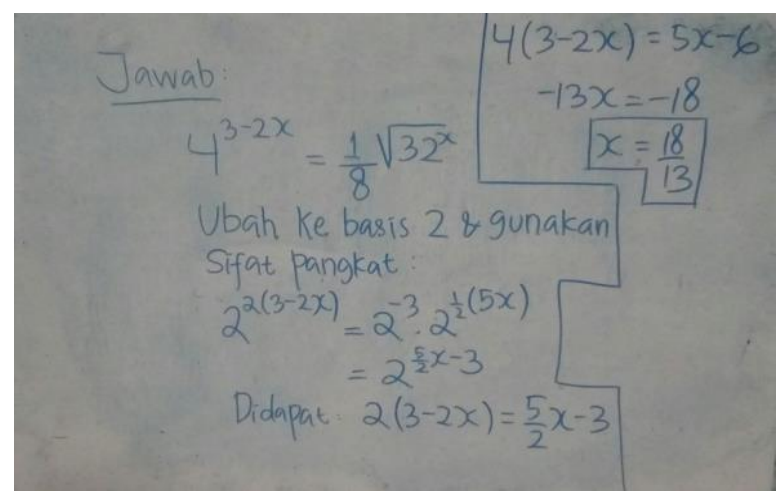

Gambar 1. Penyelesaian Soal No. 1. 
Penguatan Konsep Matematika Dalam Pembelajaran Latex untuk Siswa SMP dan SMA, Edi Kurniadi, Herlina Napitupulu , Alit Kartiwa, Riama

Sedangkan untuk penyelelesain nomor 2 diberikan sebagai berikut

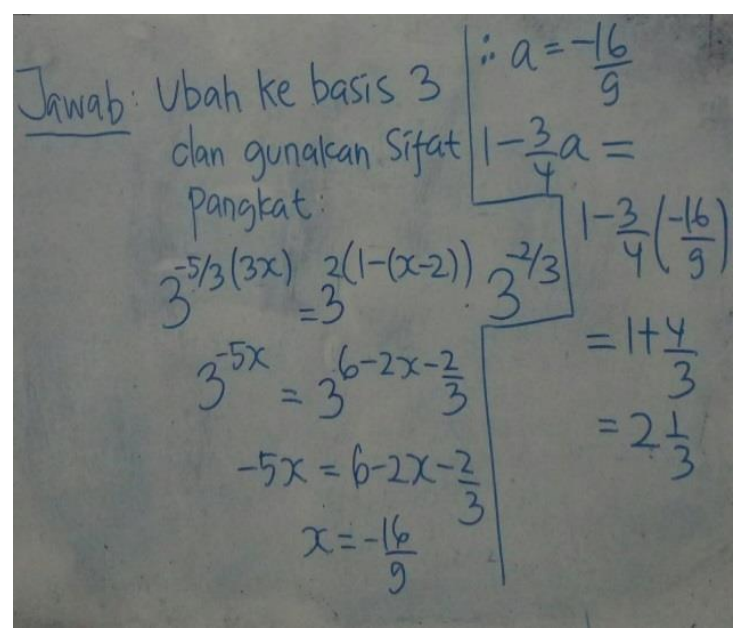

Gambar 2. Penyelesaian Soal No. 2.

Sekarang kita akan menulis ulang rumus dalam Persamaan (1) dan (2) tersebut menggunakan Latex. Panduan lengkapnya bisa dilihat misalnya (Sahid, 1999) dan (Lamport, 1986). Untuk proses instalasi, langkah pertamanya dapat mengunduh MiKTex terlebih dahulu dan sudah tersedia secara gratis di internet. Langkah keduanya memilih operator untuk pengetikan seperti TextStudio atau program yang sejenis seperti TeXnicCenter. Dalam kesempatan ini, operator pengetikan yang digunakan adalah TeXnicCenter sebagaimana ditampilkan dalam gambar berikut ini:

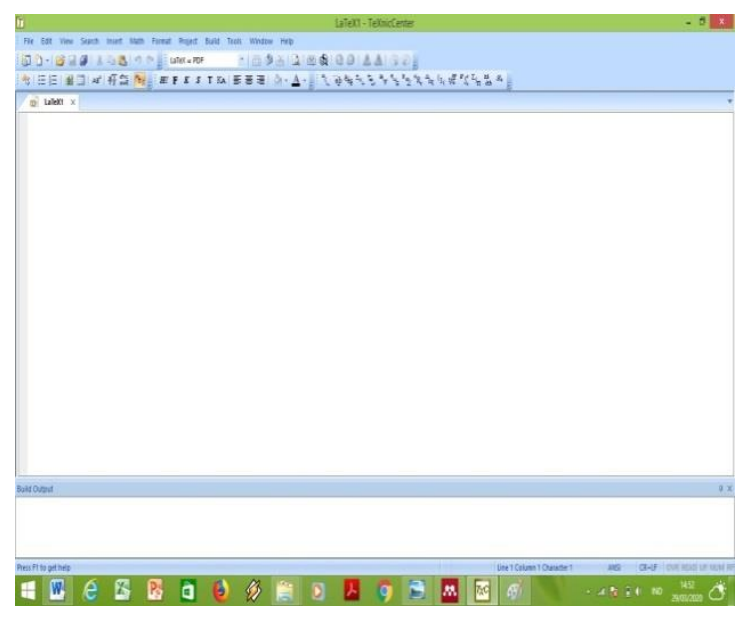

Gambar 3. Tampilan TeXnicCenter

Untuk memulai pengetikan dengan Latex ini langkahnya bisa diikuti sebagai berikut:

1. Langkah pertama kita membuat pendahuluan atau bagian utamanya terlebih dahulu yaitu dengan mengetikkan

Idocumentclass[a4paper,16pt]\{article $\}$. 
Perhatikan bahwa kita bisa memilih jenis kertas dan juga ukuran huruf yang akan digunakan.

2. Langkah ke dua kita mendeklarasikan paket matematika yang diperlukan. Dalam hal ini, kita ketikkan

$$
\text { lusepackage }\{\text { amsfonts }\}
$$

3. Langkah ke tiga adalah bagain isi atau pengetikan rumus-rumus matematinya.

Perhatikan bahwa algoritma seperti ini akan menjadikan modal dasar untuk mempelajari coding. Singkatnya sebelum suatu program dikompilasi, kita harus membuat terlebih dahulu algoritmanya.

Secara umum berikut adalah tampilan langkah satu samapai dengan tiga dalam program Latexnya.

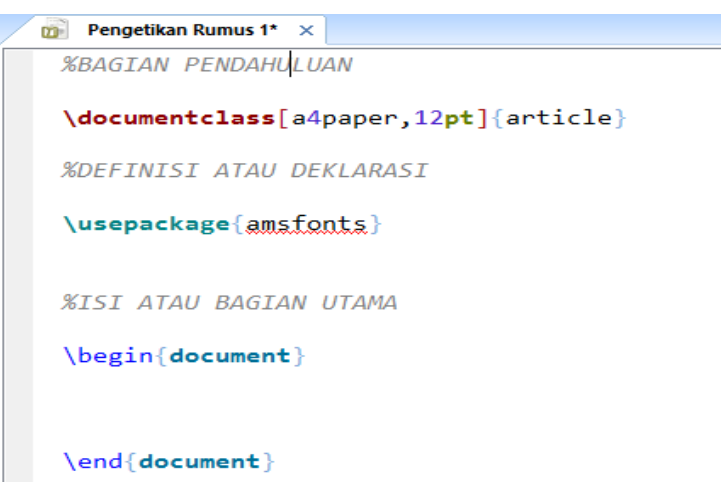

Gambar 4. Langkah 1 s.d. 3

Rumus matematika atau variabel diketik harus ditik di antara dua string \$ dan hasilnya akan disisipkan di antara teks. Jika ingin terpisah dengan teks atau beridri sendiri maka kita gunakan perintah $\$ \$ \$$ atau $\backslash[1]$. Soal nomor 1 di atas dapat ditampilkan sebagai berikut:

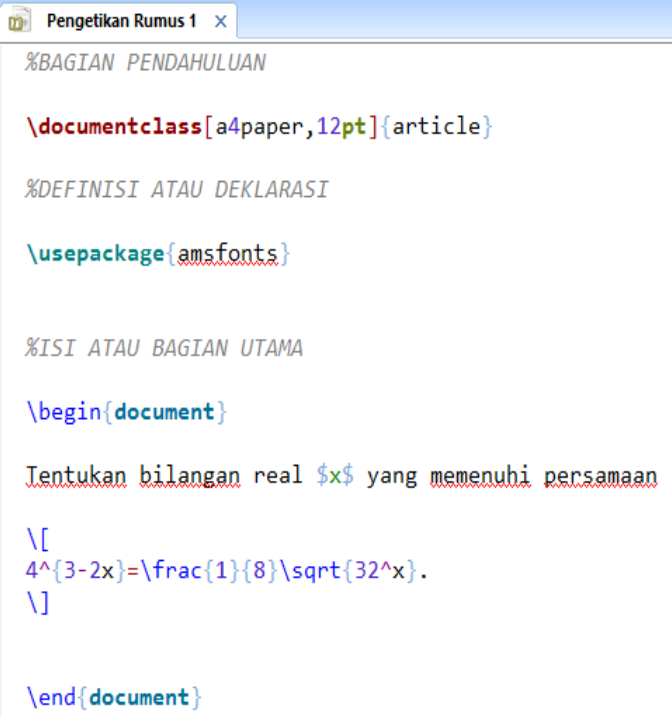

Gambar 5. Pengetikan Soal No. 1. 
Penguatan Konsep Matematika Dalam Pembelajaran Latex untuk Siswa SMP dan SMA, Edi Kurniadi, Herlina Napitupulu , Alit Kartiwa, Riama

Perhatikan Gambar 5 di atas. Karena $x$ adalah variabel maka penulisannya harus diapit oleh dua buah string \$. Untuk rumusnya sendiri kita pisahkan dari teks dan kita tuliskan di antara \[ dan \]. Untuk pangkat kita gunakan ${ }^{\wedge}$ dan pangkatnya kita tuliskan dalam \{\} . Selanjutnya notasi pecahan perintah yang digunakan adalah

$$
\backslash \text { frac }\{\text { diisi pembilang }\}\{\text { diisi penyebut }\}
$$

Sedangkan untuk akar kuadrat di tulis dengan perintah

Isqrt \{diisi dalam akar\}.

Jika akar pangkatnya lebih dari 2 kita tambahkan kurung [] sehingga perintahnya menjadi

Isqrt[diisi akar pangkat yang diinginkan]\{diisi dalam akar\}

Setelah selesai semua, hasilnya kita simpan dan programnya dikompilasi atau djalankan sehingga luarannya menghasilkan format pdf dan dapat ditampilkan sebagai berikut:

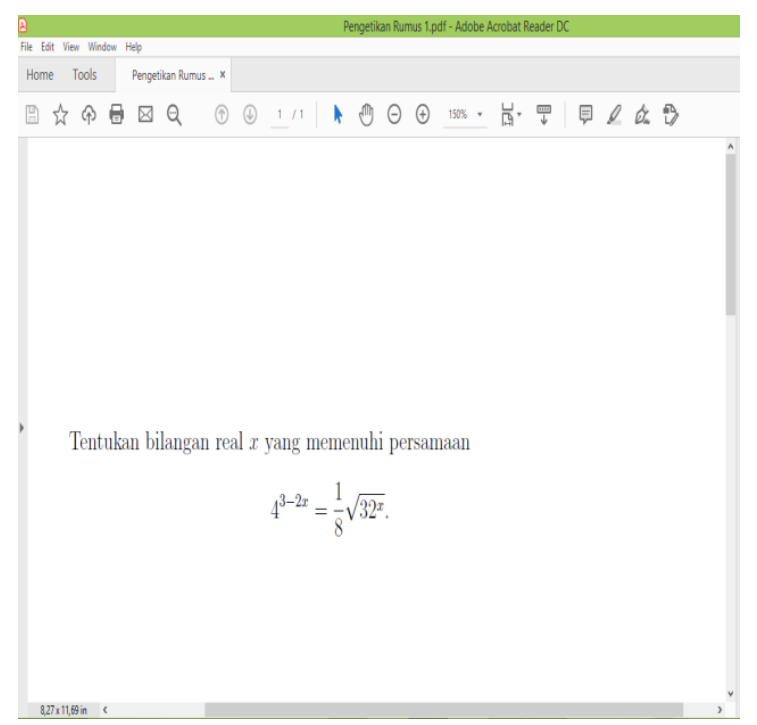

Gambar 6. Hasil kompilasi Soal No. 1

Untuk soal nomor 2 hampir persis sama dengan nomor satu. Perintah-perintah yang digunakan dapat dilihat dari Gambar 8 berikut ini 


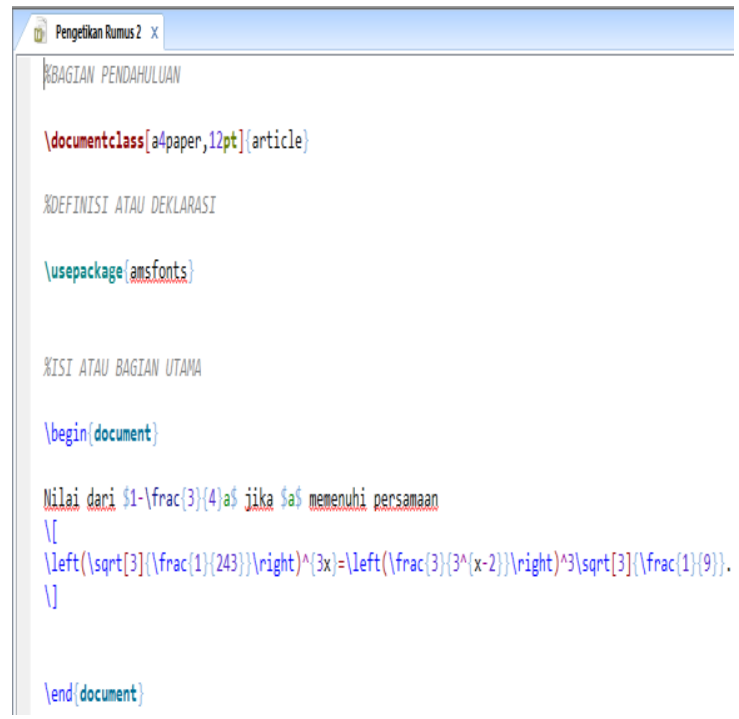

Gambar 7. Pengetikan Soal No. 2.

Dengan hasil sebagai berikut:

$$
\begin{aligned}
& \text { Nilai dari } 1-\frac{3}{4} a \text { jika } a \text { memenuhi persamaan } \\
& \qquad\left(\sqrt[3]{\frac{1}{243}}\right)^{3 x}=\left(\frac{3}{3 x-2}\right)^{3} \sqrt[3]{\frac{1}{9}}
\end{aligned}
$$

Gambar 8. Hasil kompilasi Soal No. 2

Selanjutnya untuk pembahasan nomor 3 dan 4, para siswa diberikan konsep akar dan pangkat bilangan, konsep logaritma dan juga akar-akar suatu persamaan kuadrat. Penyelesain soal-soal tersebut berturut-turut diberikan dalam Gambar 9 dan 10 sebagai berikut:

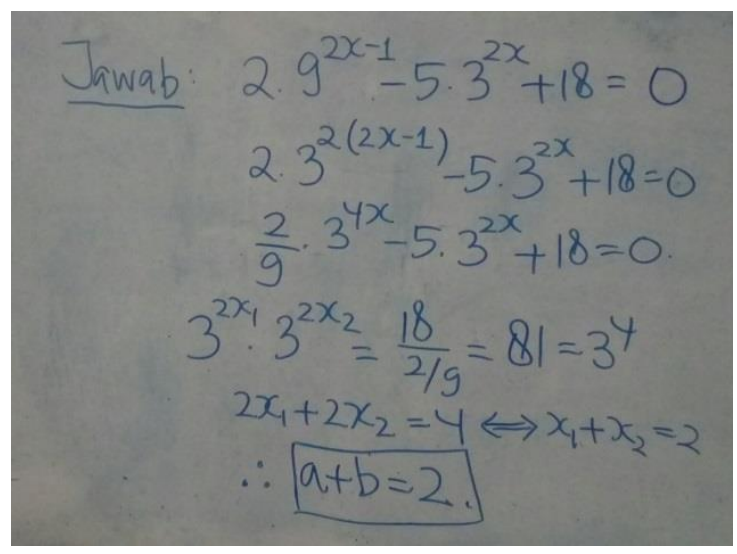

Gambar 9. Penyelesaian Soal No. 3. 
Penguatan Konsep Matematika Dalam Pembelajaran Latex untuk Siswa SMP dan SMA, Edi Kurniadi, Herlina Napitupulu , Alit Kartiwa, Riama

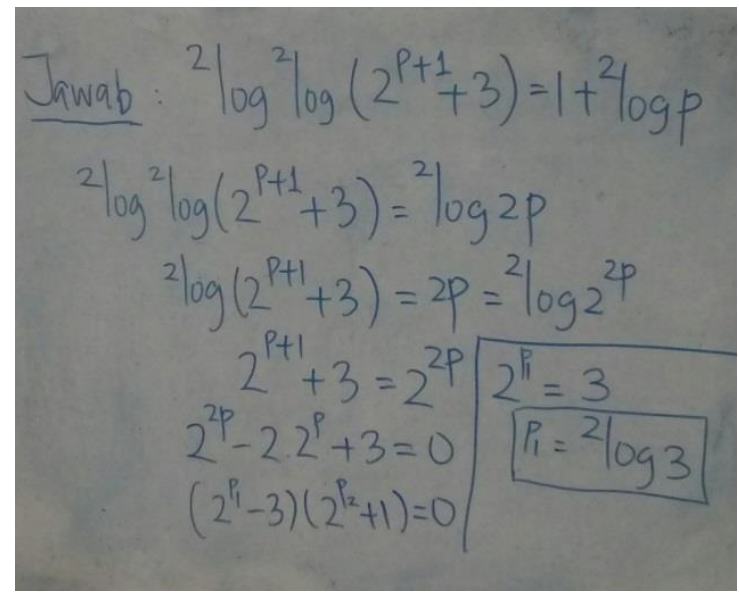

Gambar 10. Penyelesaian Soal No. 4.

Sedangkan pengetikan dalam Program Latex untuk soal nomor 3 dan 4 adalah sebagai berikut

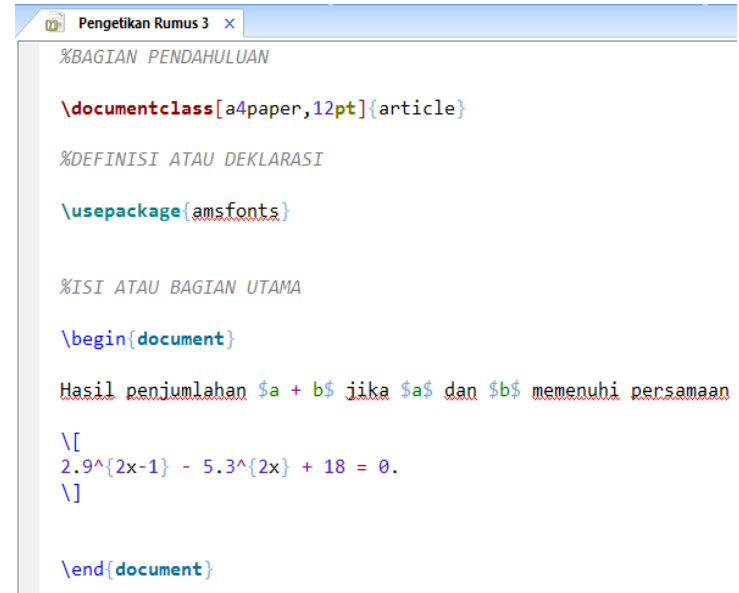

Gambar 11. Pengetikan Soal No. 3.

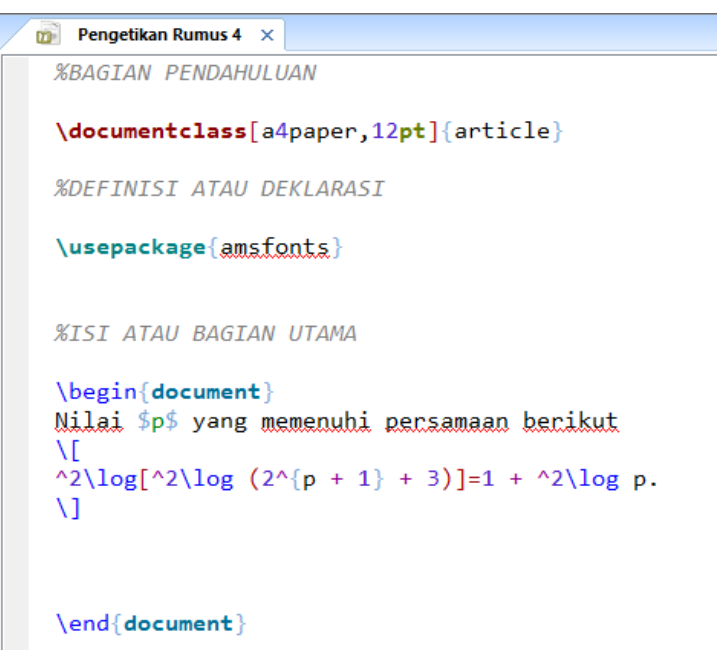

Gambar 12. Pengetikan Soal No. 4.

Ketika dikompilasi hasil pengetikan di Latex untuk soal nomor 3 adalah sebagai berikut: 


\section{Hasil penjumlahan a $+b$ jikka a dan $b$ memenuhi persamaan$$
2.2^{2 x-1}-5.3^{2 x}+18=0
$$

Gambar 13. Hasil kompilasi Soal No. 3.

Sedangkan hasil kompilasi soal nomor 4 adalah sebagai berikut:

Vilai p yang memenulhi persamaan berikut

$$
{ }^{2} \log \left[{ }^{2} \log \left(2^{2}+1+3\right)\right]=1++^{2} \log p
$$

Gambar 14. Hasil kompilasi Soal No. 4.

\section{KESIMPULAN}

Penguatan konsep matematika perlu dilakukan melalui pembelajaran yang menyenangkan. Salah satu dengan praktik sederhana seperti pengetikan rumus-rumus matematika dengan Latex. Selain bermanfaat untuk melatih logika dalam berpikir, pengetikan dengan Latex juga dapat menjadi sarana untuk belajar coding. Dengan demikian, matematika dapat diterapkan dalam kehidupan seharihari. Disarankan untuk mempelajari konsep matematika selain pangkat, akar suatu bilangan dan logaritma. Pemehaman Latex juga dapat dikembangkan untuk rumus-rumus matematika yang lebih kompleks dan implementasinya dapat digunakan $\mathrm{C}++$ atau Python.

\section{UCAPAN TERIMA KASIH}

Penulis mengucapkan terima kasih kepada Universitas Padjadjaran yang telah mendanai penelitian ini melalui Riset Percepatan Lektor Kepala (RPLK) tahun 2020 dengan nomor kontrak 1427/UN6.3.1/LT/2020 dan juga penulis mengucapkan terima kasih kepada reviewer yang telah memberikan masukan untuk perbaikan artikel ini.

\section{DAFTAR PUSTAKA}

Afifah, A. (2017). Pembelajaran matematika dengan memanfaatkan Formulator Tarsia. Jurnal Didaktik Matematika, 4(2), 152--159. 
Penguatan Konsep Matematika Dalam Pembelajaran Latex untuk Siswa SMP dan SMA, Edi Kurniadi, Herlina

Aminah, N., \& Waluya S.B, R. (2020). Integrasi teknologi dalam pengajaran matematika. Mathline: Jurnal Matematika \& Pendidikan Matematika, 5(1), 87--100.

Brown, A. (1994). The Advance of learning. Educational Researcher, 23(8), 4--12.

Hendroanto,Aan \& Fitriyani, H. (2019). Pengembangan alat pembelajaran Geoklik untuk pembelajaran geometri. Pythagoras : Jurnal Pendidikan Matematika, 14(1), 102--111.

Irawati, I. (2015). Meningkatkan aktivitas belajar siswa dengan memanfaatkan information and communication technology (ICT) pada materi penyajian data di kelas IX SMPN 5 Sabang. Jurnal Didaktik Matematika, 2(1), 46--51.

Johansyah,Muh.Deni, \& et al. (2004). Siap dan Sukse SPMB:Kumpulan Soal \& Pembahasan Matematika Tahun 2000--2004, Regional I,II,III, \&UM-UGM. Bandung: Ganesha Operation.

Khadijah, A., Maya, R., \& Setiawan, W. (2018). Analisis kemampuan komunikasi matematis siswa SMP pada materi statistika. Jurnal Pembelajaran Matematika Inovatif, 1(6), 1095--1104.

Kurniadi, E., Gusriani, N., Subartini, B., \& Napitupulu, H. (2020). Penguatan Konsep Matematika Melalui Alat Peraga Permainan Di SDN Cikuda Jatinangor. Bernas:Jurnal Pengabdian Kepada Masyarakat, 1(4), 561-568.

Lamport, L. (1986). Latex: A Document Preparation System. Addison-wesley Publishing Company.

Miatun, A., \& Khusna, H. (2020). Pengaruh geogebra online berbasis scffolding dan tingkat selfregulated learning terhadap kemampuan berpikir kritis. Pythagoras: Jurnal Pendidikan Matematika, 15(2), 124--136.

Minarni, A., Napitupulu, E.Elpis, \& Kusumah, Y. . (2020). Perangkat pembelajaran berbasis discovery learning berbantuan Microsoft excel untuk meningkatkan kemampuan pemecahan masalah statistika dan soft skills siswa SMP. Kreano, Jurnal Matematika Kreatif-Inovatif, 11(1), $1--15$.

Puspitasari, I. W., Fuazan, G. ., \& Bernard, M. (2019). Penerapan PBL dengan RME berbatuan software Geogebra untuk meningkatkan kemampuan berpikir logis matematik siswa SMP. Journal on Education, 1(4), 679--687.

Putra, E. A., Sudiana, R., \& Pamungkan, A. S. (2020). Pengembangan smarphone learning management system (S-LSM) sebagai media pembelajaran matematika SMA. Kreano : Jurnal Matematika Kreatif-Inovatif, 11(2), 36--45.

Rizali, A. (2018). Indonesia Darurat Matematika! Kompas. Retrieved from 
https://edukasi.kompas.com/read/2018/09/24/07200071/indonesia-darurat-matematika?page=2

Sahid. (1999). Pengantar Latex 2e:Petunjuk Pembuatan Dokumen Secara Efektif Bagi Para Penulis. Yogyakarta: ANDI Yogyakarta.

Septian, A., Sugiarni, R., \& Monariska, E. (2020). The application of android-based Geogebra on quadratic equation material toward mathematical creative thinking ability. Aljabar: Jurnal Pendidikan Matematika, 11(2), 261--271.

Simbolon, A. K. (2020). Penggunaan Software Geogebra Dalam Meningkatkan Kemampuan Matematis Siswa Pada Pembelajaran Geometri Di SMPN 2 Tanjung Morawa. Cendekia : Jurnal Pendidikan Matematika, 04(02), 1106--1114.

Suddin, S., \& Deda, Y. N. (2020). Education game based on Timor local wisdom as an AndroidBased Mathematics Learning Media. Aljabar : Jurnal Pendidikan Matematika, 11(2), 227--246.

Supiyati, J. (2014). Pengembangan peangkat pembelajaran bangun ruang SMP dengan pendekatan SAVI ( Somatik, Auditori, Visual, dan Intelektual). Pythagoras: Jurnal Pendidikan Matematika, 9(2), 175--185.

Wagiman, \& Sularno. (1991). Master EBTA (Materi Soal Terpilih Evaluasi Belajar Tahap Akhir) Matematika SMA. Yogyakarta: PT Intan Pariwara. 